\title{
Mercury content in the parasite-host system of Ligula intestinalis and Abramis brama and the effect of the parasite on fish muscle composition
}

\author{
Miroslava Palíková ${ }^{,}$Stanislav Navrátil ${ }^{1}$, Andrea Dvořáková1, Iveta Bedáňová ${ }^{2}$, \\ Jan Mareš̉, Olga Čelechovská ${ }^{3}$ \\ ${ }^{1}$ University of Veterinary and Pharmaceutical Sciences Brno, Faculty of Veterinary Hygiene and Ecology, \\ Department of Ecology and Diseases of Game, Fish and Bees, ${ }^{2}$ Department of Veterinary Public Health, \\ Animal Protection and Welfare, Brno, Czech Republic \\ ${ }^{3}$ Mendel University, Faculty of Agronomy, Department of Zoology, Fisheries, Hydrobiology and Apiculture, \\ Brno, Czech Republic \\ ${ }^{4}$ University of Veterinary and Pharmaceutical Sciences Brno, Faculty of Veterinary Hygiene and Ecology, \\ Department of Biochemistry and Biophysics, Brno, Czech Republic \\ Received January 30, 2014 \\ Accepted April 24, 2014
}

\begin{abstract}
The bioaccumulation potential of parasites resulting from the competition for chemical elements including heavy metals represents a valuable instrument of evaluating the functions of the parasite-host system. In the present study, the effect of the parasite-host system of Ligula intestinalis and Abramis brama on the mercury concentrations and fish muscle composition of infected and non-infected fish was evaluated. Nine parasitized and seven non-parasitized fish were studied. The total mercury content in the samples was determined by the atomicabsorption spectrophotometry method. Standard indicators of the chemical composition of muscles (dry matter, crude protein, fats, and ash) and a spectrum of fatty acids were evaluated. The mean mercury concentration in the biomass of plerocercoids was $0.045 \pm 0.025 \mathrm{mg} \cdot \mathrm{kg}^{-1}$; about $\times 7$ lower compared to fish muscles. The mean mercury concentration in the muscles of infected and non-infected fish was $0.36 \pm 0.11$ and $0.24 \pm 0.1$, respectively. There was no difference in the composition of fish muscles and the spectrum of fatty acids. Ligula intestinalis takes nutrients from the fish body but according to the results of our study, the withdrawal of the monitored nutrients was uniform without any selection. Mercury is not efficiently accumulated by plerocercoids of Ligula intestinalis. This study brings novel data for this heavy metal and for this parasite host system.
\end{abstract}

Tapeworm, fish, heavy metal, bioaccumulation

The bioaccumulation potential of parasites resulting from the competition for chemical elements including heavy metals represents a valuable instrument of evaluating the functions of the parasite-host system (Sures et al. 1999). Many studies describe higher concentrations of different heavy metals in various parasites than in the tissues of fish, and the possibility of decreasing the heavy metal concentrations in the host by parasite bioaccumulation (Gabrashanska and Nedeva 1996; Tenora et al. 2000; Barus et al. 2001; Barus et al. 2012). Parasites (tapeworms) may lower the heavy metal (HM) burden of their hosts and thus prevent their intoxication (Turcekova and Hanzelova 1999). Also fish parasites (especially Acanthocephala and Cestoda) are considered as perceptive bio-indicators of polluted aquatic environment (Turcekova and Hanzelova 1997; Sures et al. 1999; Sures et al. 1997).

The aim of this study was to find mercury concentrations in the parasite-host system of Ligula intestinalis and Abramis brama and evaluate the influence of the parasite-host system on the fish muscle composition. 


\section{Materials and Methods}

Fish

Nine infected and seven non-infected bream (Abramis brama) were studied. Fish were caught in the Mostiště water reservoir using an electric aggregate. The plerocercoids of Ligula intestinalis and samples of muscles of intermediate host fish were studied. Characteristics of the studied fish are presented in Table 1.

Table 1. Characteristics of studied non-infected bream and bream infected with Ligula intestinalis.

\begin{tabular}{llccc}
\hline & Length $(\mathrm{mm})$ & Weight $(\mathrm{g})$ & Age (years) & $\mathrm{n}$ \\
\hline Infected & $384.4 \pm 11.2$ & $515.6 \pm 88.7$ & $6.1 \pm 1.4$ & 9 \\
Non-infected & $357.1 \pm 52.2$ & $499.3 \pm 243.1$ & $5.4 \pm 1.3$ & 7 \\
\hline
\end{tabular}

Data are expressed as mean \pm standard deviation

Experimental procedures and laboratory analyses

The total mercury content in samples was determined by the atomic-absorption spectrophotometry method (AAS) using a single-purpose mercury analyser AMA-254 (ALTEC Ltd., Czech Republic). The detection limit was $0.01 \mathrm{ng} \mathrm{Hg}$ absolutely. Results were validated by the following standard reference materials: CRM No. 278 (mussel tissue of Mytilus edulis - BCR) and MA-B-3/TM (fish homogenate - IAEA). The content of mercury is expressed in $\mathrm{mg} \cdot \mathrm{kg}^{-1}$ of fresh tissue. The coefficient $\mathrm{R}$ (ratio) was calculated to evaluate the efficiency of mercury accumulation as the proportion of the parasite and host mercury concentrations (Sures et al. 1999).

Standard indicators of the chemical composition of muscles (dry matter, crude protein, fats, and ash) and spectrum of fatty acids (FA) were evaluated. Lipids were determined according to Soxhlet using $12 \mathrm{~h}$ extraction by diethylether (GLF 1041, Deutchland). Dry matter content was determined by drying the sample up to a constant weight at $105^{\circ} \mathrm{C}$ (for $24 \mathrm{~h}$ ). Ash level was determined using a gravimetric method of incineration in an electric oven at $550{ }^{\circ} \mathrm{C}$. Crude protein content was determined by Kjehldahl method using the Kjeltec 23 apparatus (Tecator, Sweden), multiplied by the coefficient 6.25. The spectrum of fatty acids was analysed using gas chromatography (HP 4890D chromatograph, Hewlett Packard, USA) following extraction with a mixture of methanol and chloroform (Folsch et al. 1957).

\section{Statistical analysis}

Statistical analyses were performed using the Unistat program (5.6 for MS Excel). Results from different treatment groups were compared by one-way analysis of variance (ANOVA). The relation between mercury concentrations in plerocercoids and in fish muscle was assessed by Pearson correlation. The differences were considered significant at $P \leq 0.05$.

\section{Results}

\section{Muscle composition}

Muscle composition of infected and non-infected fish is presented in Table 2. The composition of fatty acids is presented in Table 3 . There were no significant differences in the muscle composition and in the composition of fatty acids between infected and noninfected fish $(P>0.05)$.

Table 2. Muscle composition of non-infected bream and bream infected with Ligula intestinalis.

\begin{tabular}{lcccc}
\hline & Dry matter (\%) & $\begin{array}{c}\text { Crude proteins } \\
\text { (\% of DM) }\end{array}$ & $\begin{array}{c}\text { Fats } \\
(\% \text { of DM })\end{array}$ & $\begin{array}{c}\text { Ash } \\
(\% \text { of DM })\end{array}$ \\
\hline Infected fish & $19.20 \pm 1.7$ & $85.8 \pm 2.5$ & $6.79 \pm 3.8$ & $6.41 \pm 0.8$ \\
Non-infected fish & $20.11 \pm 1.7$ & $85.10 \pm 4.0$ & $6.59 \pm 4.3$ & $5.97 \pm 0.9$ \\
\hline
\end{tabular}

Data are expressed as mean \pm standard deviation; DM - dry matter 
Table 3. Composition of fatty acids in bream muscles of noninfected fish and fish infected with Ligula intestinalis in \%.

\begin{tabular}{lcc}
\hline & Infected fish & Non-infected fish \\
\hline SFA & $32.35 \pm 4.7$ & $29.53 \pm 5.2$ \\
MUFA & $22.01 \pm 6.5$ & $25.77 \pm 6.8$ \\
PUFA & $45.64 \pm 3.0$ & $44.70 \pm 2.2$ \\
n-6 PUFA & $12.88 \pm 2.4$ & $12.43 \pm 2.4$ \\
n-3 PUFA & $32.76 \pm 3.3$ & $32.26 \pm 3.3$ \\
n-3 / n-6 & $2.65 \pm 0.7$ & $2.70 \pm 0.7$ \\
\hline
\end{tabular}

Data are expressed as mean \pm standard deviation; SFA saturated fatty acids, MUFA - mono-unsaturated fatty acids; PUFA - poly-unsaturated fatty acids

\section{Mercury content}

The total mercury concentrations in the muscle of non-infected and infected fish were $0.24 \pm 0.1 \mathrm{mg} \cdot \mathrm{kg}^{-1}$ and $0.36 \pm 0.1 \mathrm{mg} \cdot \mathrm{kg}^{-1}$ of fresh weight (FW), respectively. The difference between non-infected and infected fish was not significant $(P>0.05)$. The total mercury accumulated in the biomass of plerocercoids at concentrations of $0.045 \pm 0.02 \mathrm{mg} \cdot \mathrm{kg}^{-1}$ of fresh weight was significantly lower compared to the muscles of intermediate host fish $(P \leq 0.01)$. Calculated $\mathrm{R}$ values were $0.08-0.16$. Figure 1 well documents the dependence of mercury concentration in plerocercoids on mercury concentration in fish muscle. By using Pearson correlation the dependence was found to be highly significant $(P \leq 0.0001, \mathrm{r}=0.9381)$.

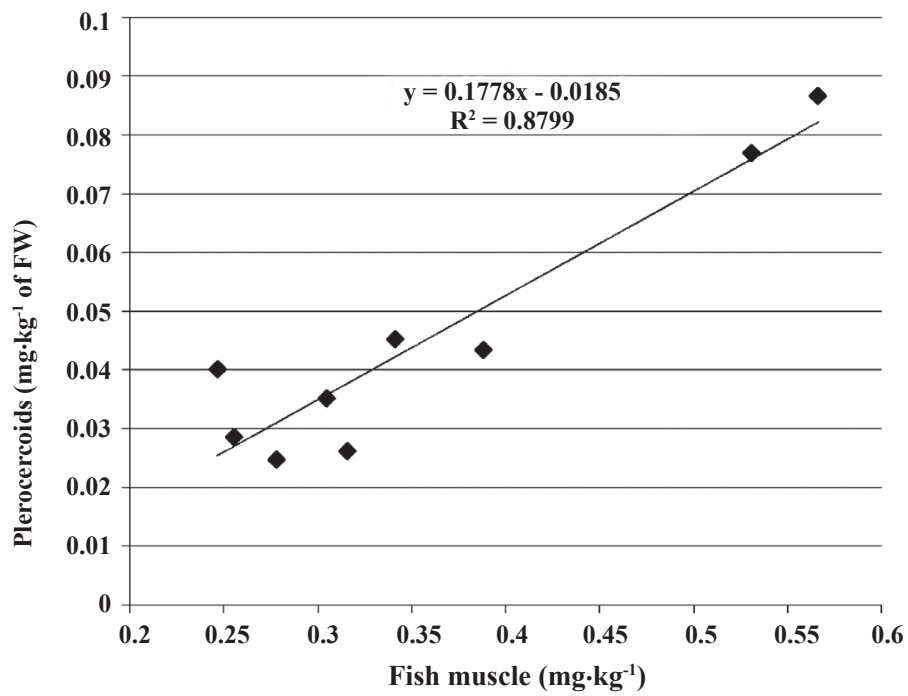

Fig.1. Dependence of mercury concentration in plerocercoids on mercury concentration in fish (bream) muscle (in $\mathrm{mg} \cdot \mathrm{kg}^{-1}$ of fresh weight)

\section{Discussion}

Many studies describe higher concentrations of various heavy metals in plerocercoids Ligula intestinalis than in muscles of fish. Gabrashanska and Nedeva (1996) observed higher concentrations of $\mathrm{Cu}, \mathrm{Cr}$ and $\mathrm{Zn}$ in plerocercoids L. intestinalis than in muscles of Alburnus alburnus. Barus et al. (2012) found $\times 12.5-18.9$ more $\mathrm{Pb}, \times 2.3-3$ more $\mathrm{Cd}$ and $\times$ 4.4-14.1 more $\mathrm{Cr}$ in Ligula intestinalis compared to the muscles of intermediate hosts. Similar finding was reported also by Tenora et al. (2000). The bioaccumulation potential is not restricted for Ligula intestinalis only. Barus et al. (2012) detected in the system Bathybothryum rectangulum vs. barbell (Barbus barbus) higher concentrations of $\mathrm{Pb}, \mathrm{Ni}$ 
and $\mathrm{Cr}$ in the tapeworm than in the muscle, but similar concentrations of $\mathrm{Cd}$. Also Pascoe and Cram (1977) found lower concentrations of $\mathrm{Cd}$ in plerocercoids of the tapeworm Schistocephalus solidus compared with muscles of Gasterosteus aculeatus. Similarly Svobodova et al. (1996) found lower $\mathrm{Hg}$ concentrations in plerocercoids of Ligula intestinalis than in tissues from the roach (Rutilus rutilus). Lower mercury concentrations $\left(0.05-0.18 \mathrm{mg} \cdot \mathrm{kg}^{-1} \mathrm{FW}\right)$ were found also in Anguillicola crassus in comparison with muscle concentrations (0.16-0.83 $\mathrm{mg} \cdot \mathrm{kg}^{-1} \mathrm{FW}$ ) in Anguilla anguilla (Palikova and Barus 2003). In the present study we also found lower concentrations of mercury in the plerocercoids than in the muscles of intermediate host. Although the plerocercoid concentrations were about $\times 7$ lower than in the muscles, very highly significant correlation was found between the concentrations in the muscle and in the plerocercoids. Importantly, the higher mercury concentration was found in the muscle of the intermediate host, the higher mercury concentration was found in the plerocercoid.

The accumulation of heavy metals by parasites from host tissues can lead to significantly decreased concentrations of some HM in infected fish in comparison with non-infected fish. Gabrashanska and Nedeva (1996) described an interesting aspect of competition for chemical elements in the parasite-host system and found lower concentrations of $\mathrm{Cu}$ and $\mathrm{Zn}$ in the muscles of fish parasitized by tapeworms compared to non-parasitized fish. Similarly Turcekova and Hanzelova (1999) found in fish parasitized with Proteocephalus percae lower concentrations of $\mathrm{Cd}$ and $\mathrm{As}$ but higher concentrations of $\mathrm{Pb}$. Also Barus et al. (2012) showed that uninfected barbells (Barbus barbus) exhibited more $\mathrm{Pb}, \mathrm{Ni}$ and $\mathrm{Cr}$ than barbell infected with tapeworm Bathybothrium rectangulum. We did not find significant differences in mercury concentrations between infected and non-infected fish; however, mercury concentrations in infected fish were higher. Because the parasite is dependent on substances taking on from the fish body, it is the only possible way of mercury entering the plerocercoids. Although its concentrations in plerocercoids are dependent on concentrations in the host tissues, the bioaccumulation potential of the plerocercoid $L$. intestinalis is low, and the mean calculated $\mathrm{R}$ value is 0.12 .

Ligula intestinalis draws important substances from the fish body. However, on the basis of our analysis we concluded that the withdrawal of nutrients monitored in the present study was uniform without any selection.

Of much interest is the discovery that infected fish were caught only in littoral areas of the water reservoir. Only low percentage of non-infected fish was caught in this area. Noninfected fish were caught particularly in free water. This finding may be connected with the spectrum of the feed. Fish have easier access to natural feed with copepods, the first intermediate hosts of L. intestinalis. On the other hand, there is the possibility that infected fish assemble mainly the littoral areas, and there they are easier prey for predators (birds, e.g. gulls - Larus sp.), definitive hosts of L. intestinalis.

\section{Acknowledgements}

The study was supported by the project NAZV QI91C001.

\section{References}

Barus V, Tenora F, Kracmar S, Prokes M 2001: Accumulation of heavy metals in the Ligula intestinalis plerocercoids (Pseudophyllidea) of different age. Helmintologia 38: 29-33

Barus V, Simkova A, Prokes M, Penaz M, Vetesnik L 2012: Heavy metals in two parasite-host systems: tapeworm vs. fish. Acta Vet Brno 81: 313-317

Folsch J, Lees M, Sloane-Stanley GH 1957: A simple methods for the isolation and purification of total lipids from animal tissues. J Biol Chem 226: 497-509

Gabrashanska M, Nedeva I 1996: Content of heavy metals in the system fish-cestodes. Parassitologia 38: 58

Palikova M, Barus V 2003: Mercury content in Anguillicola crassus (Nematoda) and its host Anguilla anguilla. Acta Vet Brno 72: 289-294 
Pascoe D, Cram P 1977: The effect of parasitism on the toxicity of cadmium to the three-spines stickleback, Gasterosteus aculeatus L. J Fish Biol 10: 467-472

Sures B, Siddal R, Taraschewski H 1999: Parasites as accumulation indicators of heavy metal pollution. Parasitol Today 15: 16-21

Sures B, Taraschewski H, Siddal R 1997: Heavy metal concentrations in adult acanthocephalans and cestodes compared to their fish host and to established freeliving bioindicators. Parassitologia 39: 213-218

Svobodova Z, Groch L, Drabek P, Modra H, Drabkova L, Gelnar M, Koubkova B, Sebelová S 1996: Utilization of biological and biochemical markers of fish as that of indicators of environment contamination by mercury (in Czech). Final Report, University Veterinary and Pharmaceutical Sciences Brno, 32 p.

Tenora F, Barus V, Kracmar S, Dvoracek J 2000: Concentrations of some heavy metals in Ligula intestinalis plerocercoids (Cestoda) and Philometra ovata (Nematoda) compared to some their host (Osteichthyes). Helmintologia 37: 15-18

Turcekova L, Hanzelova V 1997: Parasites as possible bioindicators of water pollution. $X^{\text {th }}$ Wroclaw Parasitol Conf, Abstract of communications, Karpacz, p.53

Turcekova L, Hanzelova V 1999: Concentrations of Cd, As and $\mathrm{Pb}$ in non-infected and infected Perca fluviatilis with Proteocephalus percae. Helmintologia 36: 31 